PRODUCTION

ENGINEERING
2014, Vol. 4, No. 3, pp 29-31

ISSN 2353-5156 (print version)

ISSN (online version)

\title{
FAM-FMC system as an alternative element of the software used in a grain and flour milling enterprise
}

\author{
Szymon T. Dziuba ${ }^{1}$, Barbara Śron ${ }^{2}$ \\ ${ }^{1}$ Ph.D., Wroclaw University of Economics, Poland, Faculty of Engineering and Economics, Institute of Chemistry and Food Technology, \\ Department of Quality Analysis, email: szymon.dziuba@ue.wroc.pl \\ ${ }^{2}$ Employee of the research company
}

\begin{abstract}
Processes of computerization have become a standard in contemporary production plant methods. Implementation of these processes is aimed at limiting activities which had up to that point, been performed manually. Dedicated computer systems are being developed according to the requirements imposed on concrete enterprises with consideration of their manufacturing specificity. These adjusted systems facilitate and accelerate production and improve its performance while helping maintain a consistent level of quality for the final product. Flour mill laboratories use the software to record and facilitate computation of the measurements. This study is aimed at analysing the potential for implementation of the FAM-FMC system as a tool to support production of flour with parameters that match specific customer expectations.
\end{abstract}

Keywords: Grain and flour milling industry, quality, flour, production support systems.

\section{Introduction}

In order to properly develop and implement a system for support of production processes (including logistics and quality processes), one should consider individual stages in production of a specific product (INGALDI M., JAGUSIAK-KOCIK M. 2013, INGALDI M. 2013).

In a flour mill, the production cycle begins with acceptance of raw materials. A representative sample is always taken from each delivery that arrives at the plant. Next, the samples are tested in a laboratory. The grain is subjected to basic analysis. The parameters determined include (JURGA R. 2009; KIRSCH B. 2008): humidity, density, uniformity, contaminants, protein content, gluten content, falling numbers, sedimentation and hardness.

If the basic results suggest a very good quality of the grain, additional rheological tests are also carried out. Depending on the parameters met by grain, the grain is classified for production of a particular type of flour (GĄSIOROWSKI H. 2004; FRANKEN J. L. 1992; KHAN K., SHEWRY R., P. 2009). 
Contemporary mills use the principle that only the grain which meets all the parameters can reach production and therefore, only the flour that meets particular standards and specifications can be sent to a customer (JANKIEWICZ M. 2009, JURGA R. 2009).

\section{Characterization of production specificity of the enterprise}

The enterprise which is the subject of this study has its headquarters in the Greater Poland region. The location is excellent due to the neighbouring agricultural areas. In order to meet high quality expectations of the customers, it imports grains with specific parameters which in Poland are impossible to be achieved. Combined with modern equipment, using high-quality raw materials in a manufacturing cycle guarantees a very high quality of special flours for industrial customers as well as standard baking flours and packaged flours in the retail market.

It has focused on production of niche flours i.e. flours dedicated to a specific type of product. These types of flour make the work of bakers or confectioners easier and limit or even eliminate the need for using other ingredients. Each type of special flour is made from special mixtures of grains so that the flour meets particular requirements defined by customers. Each product necessitates a special manufacturing process and is subjected to individual supervision in the laboratory. Furthermore, customers often require a specific way of packaging and means of transport (own study based on the materials from the enterprise).

\section{Study aim}

The main aim of the study is to provide a preliminary feasibility analysis for implementation of the Fail Assessment Method - Flour Mixture Choosing (FAM-FMC) system as an additional tool to support production of flour with desired parameters by the customer in the enterprise studied. In order to perform the research task, the study used the following research methods: observation, induction, descriptive method, free interview.

\section{Description of the system in the enterprise}

Each process of accepting raw materials, flour production and packaging of the finished product, order processing and all the laboratory tests performed must be documented. In order to track all the processes that are performed in the enterprise, the company decided to implement a single compatible software program which ensures trouble-free data exchange between the organizational units in the enterprise. This allows for quick verification of inventory levels, acceptance of grain supplies, orders placed and processing orders in a specific period of time. The documentation of finished goods must also be recorded.

Software for recording and monitoring of all the processes in the enterprise was implemented in the enterprise. The software is dedicated to the needs and requirements of the business. It integrates all the elements of the organizational structure of the mill.

The software features an option for tracking the supply chain with contracts signed with bigger grain manufacturers. This allows for improved organization of the deliveries of raw material through notification of each vehicle for a specific day and hour of acceptance.

The software also allows for graphical representation of the layout of the chambers in the elevator and the mill with goods stored in individual chambers and labels assigned. This helps verify the status of the raw material present in chambers and the level of filling a particular chamber with respect to its overall capacity.

After acceptance of the grain to elevator, the system moves on to recording the following operations (own study based on the materials from the enterprise):

- Mixing order or inter-chamber transfer order.

- Grain release to mill order.

- The order to release grain to production chambers

- Production order.

- Flour mixing order.

- Packaging order.

It should also be noted that the software also represents the source of important information concerning suppliers, customers and employees. The data 
contained in the software characterize the structure of the enterprise.

\section{Opportunities for system implementation}

Production of flour with particular parameters adjusted to individual customer needs has become a specific market niche.

Therefore, mixing divisions in flour mills should be equipped in a system to support mixing process.

To this end, a computer system FAM-FMC is especially useful. The FAM method is used for assessment and evaluation of components of flours and their mixtures.

FAM-FMC system is a user-friendly tool to support production of flours which can be described through the following components:

The main menu performs all the system functions and offers the choice of program blocks. The most important blocks include:

- Preview and edition of the data.

- Mixture of two flours.

- Mixture of three flours.

- Mixture of four flours.

\section{Conclusions}

In conclusion, the study demonstrated that FAMFMC system can be successfully used as a supplement for the implemented program since:

a) The speed of system operation is equal to the speed of decision concerning the choice of proper flours being the components of the special flour mixtures.

b) The program is capable of analysis of six parameters (humidity, gluten content, gluten index, falling number, ash content, protein content) in composition of flours, which represents a significant improvement since only two parameters were analysed so far. c) The program enables the choice of parameters in case of a failure of the laboratory equipment.

d) It is possible to obtain many mixtures of special flours with the highest quality specified by the customer.

e) It is also possible to use any flour which has not been used for other purposes and remains present in the enterprise as stock in the warehouse.

\section{References}

1. Franken J., L. Nov. 1992. Automated process control. How do I get started?. Assoc. Oper.Millers Tech. Bull. p. 6117-6119

2. GĄSIOROWSKI H. (red) 2004. Pszenica chemia $i$ technologia. Państwowe Wydawnictwo Rolnicze i Leśne, Poznań 2004

3. IngALDI M., JAGUSIAK-KocIK M. 2013. The Use of Magnificent Seven and FMEA Method in Quality Analysis of the Food Product. [In:] Quality Improvement of Food Products. Monography. Ed. Stanisław Borkowski, Dorota Klimecka-Tatar. University of Malibor, Celje Slovenia. p. 80-90

4. INGALDI M. 2013. Company strategy determination in the food company with the use of the SWOT method. Forum Manazera. No 2. p.1720.

5. JANKIEWICZ M. January 2009. Ogniwa tańcucha technologicznego $w$ przetwórstwie zbóż dziś: dokonania, potrzeby, perspektywy. „Przegląd Zbożowo-Młynarski”. pp. 11-12

6. JURGA R. July 2009. Charakterystyka niektórych parametrów przemiatu. „Przegląd zbożowomłynarski”. pp. 34-35

7. KHAN K., SHEWRY R., P. 2009. Wheat. Chemistry and technology, AACC International Inc. Minnesota

8. KIRSCH B. 2008. Fachkunde Müllereitechnologie - Werkstoffkunde. Bayerischer Müllerbund e. V., München 